\title{
Kim Addonizio: A Poet with Duende
}

Shortly before this interview, Kim Addonizio's Tell Me (BOA Editions, 20oo) was named a finalist for the National Book Award. Though Tell Me didn't win, this honor showed that Addonizio's gritty, down-to-earth poems were finally starting to get the respect they deserved.

RVC: A lot of writers are becoming cyber-savvy, but you seem years ahead of them with your own web page, Internet-available poems, and personal online journal. How did all this come about? Is online publication and sharing your work via a personal webpage in some sense different, perhaps more public, than sharing your work in journals or books? Has it affected you as a writer?

KA: A few years ago, when Dorianne Laux and I were working on our book The Poet's Companion, we were just getting online and were only vaguely aware of what the web had to offer. We had to get a lot of help with the chapter we called "Writing in the Electronic Age." Then, suddenly, it seemed everyone was on the web, with an e-zine or a homepage for a print journal or an author's site. My own site began as a way to help promote my private classes, so that I didn't have to spend so much time on the phone going over what groups were scheduled and how I approached poetry. Then, I wanted to do something more that would be ongoing, and I started keeping an occasional journal, trying to focus it mostly on writing. I see it as a space to share a bit of my process, and to pass on the things that sustain me, and occasionally to rant or whine. It's on the Internet, true, but it doesn't feel like a big public forum. I have no idea how many people see it. I don't try to make the writing literary or anything; I pretty much sit down and write about whatever's on my mind at the time.

I think a lot about "the confessional," in terms of this and in terms of my poetry, which has been called confessional by some. Of course, they're leaving out a big chunk of my work, like Jimmy $\mathcal{E}$ Rita, a book that is a verse novel, and lots of other poems that focus on the world rather than the self. And it's true that I have plenty of 
poems about me, me, me-at least, that's their surface. But my hope, my aim, is to transcend the personal, to use it for art-which to me means that you make a connection, you stir something up in someone else. If I fail to do this it's because I haven't adequately transformed the subject matter. If I think my experience is special, and if the poem (or web journal) reads this way, I've failed. It's a great challenge for the ego, really, the part that just wants to be admired. Or the part that simply needs, sometimes desperately, to be seen. I guess what I'm saying is that I'm really aware of the dangers of writing this way; there are a lot of psychic snares. But what I value in poetry is exactly that: encountering another consciousness on the page, experiencing the other in the same way we experience it in love. A successful poem is ultimately an enlargement of self, and speaks to a spiritual hunger.

RVC: It's interesting that you use the word "hunger." Billy Collins calls the poems in Tell Me "stark mirrors of self-examination" that you look into "without blinking." Now that I'm teaching Tell Me in a poetry class here at the University of Wisconsin-Madison, and having read it maybe eight or nine times through, I wouldn't disagree with him, but I'd say rather that this book is about "hunger." It's a hunger for self-knowledge, a hunger for worldliness, a hunger for love, a hunger for the sake of hunger, and, of course, spiritual hunger. Could you say something about these intriguing lines from your poem "Generations": "I walk the night city, looking up at lit windows, / and there is no table set for me, nowhere / I can go to be filled"?

KA: In "Generations" I was writing about my search for my heritage, but hopefully readers can find their own search, their own hunger, in it as well. That's one reason I say somewhere in the poem, "This is the city / of grandparents, immigrants, arrivals"-that is, it's not only my story. It's the typical story, in fact, for my generation-the second generation born in America. The first typically wants to distance itself from the old country, to assimilate. Whereas of course the grandparents, the immigrants, are often trying to hold on to the traditions of the country they've left. In writing about what is for me a personal search, there is the knowledge that I'm not the only one-so that if I can write it in a way that doesn't seem to privilege 
my search over your search, I've accomplished what I mean by transcending the personal. Finding the universal in the particular is part of it. It goes back to the analogy of falling in love. You fall in love with particular people-you learn the history of their scars, the things they're afraid of, the moments in their lives that defined them in one way or another. And when you lose a lover it's those particularities that torment you. I think poetry can work the same way: you enter someone's particular experience (which of course is mental and imaginative, not only, or necessarily at all, autobiographical) and you feel an intimacy that allows you to identify, or else maybe to understand and enter a different way of seeing the world.

RVC: Before we talk about you being a chosen as a finalist for the National Book Award for poetry, let's talk a bit more about the book itself. Could you give some background on the writing of Tell Me?

KA: Well, those are just the poems of the last several years, or some of them. I cut about thirteen from the book; some weren't very good, some went over the same territory as other poems. There are still too many of those. What I discovered in putting this book together was how narrow the range of my obsessions really is. Love, death, suffering. Of course, those are what all poetry is about. That's what life is. Along with videos, chardonnay and cosmopolitans, homemade tamales and pan-seared salmon, bad sex and comfortable sex and dissolve-yourself-into-the-pulsing-stream-of-light-with-anotherhuman-being sex. Along with raising a daughter alone and worrying about money and learning blues harmonica and writing a couple of failed novels, and trying to teach people to write poetry which is basically impossible, but extremely interesting, and moving into and out of a couple of relationships (love and suffering) and people getting cancer (love, death and suffering) and being depressed by the world (too much death and suffering and not enough love). That's the background of the book.

RVC: I see a lot of those same themes and ideas operating in different ways in your earlier books, including your short story collection, In the Box Called Pleasure, which was published in 1999 by Fiction Collective 2. Both the stories in this collection and much of 
your recent poetry seems to stem from a similar tough-girl voice, a narrator with grit, guts, duende. What's the relationship between your fiction and your poetry? And which did you start out doing?

KA: I started out writing poetry. I've been writing fiction almost as long, but more intermittently and with less success. I finally gave up trying to write a traditional story, and that freed me a bit. Most of my stories run on voice. I'm not very good at plot or structure. I think that's why I had trouble with the novels; it's difficult to sustain a voice-driven piece for a long time. What I like about poetry is that you can get right to the heart of the matter. Sometimes, when I pick up a novel in a bookstore, I get bored with all the warm-up: It was this kind of day, blah blah blah. Not to say that's the fault of the writer. It's me. I want to dive into something, not wait for it to develop. Maybe it's attention deficit since I'm a TV kid.

As for tough girl, I don't know. I guess it depends on where you're standing. The women in In the Box Called Pleasure, several of them anyway, are all fucked up, and barely keeping it together. I think that's the kind of character I've been most interested in, in my fiction-and I include Jimmy \& Rita in that category. And, I'm very interested in sex and love. One reviewer called In the Box Called Pleasure "grim erotica," which is not at all what I had in mind. There's nothing erotic about the book; it's an investigation of sex. It's meant to explore, not to titillate. To dissect, even. To lay out the territory of sexual harm, sexual desire, sexual fixation. Along with a few other things that are contingent, but seemed to fit with those themes. I hope to write more fiction one day, but I'll always, I think, be essentially a poet. Poetry is my favorite space to inhabit. It's kind of great that you can't make money at it. I mean, I want enough money to live on and write, but that situation keeps you honest, you know?

RVC: I think I do know what you mean. A few months ago, Campbell McGrath said that if poetry held the type of appeal that movies did, it'd become big-box office too, which would make it equally corrupt and equally bad. Let me ask the big question-what does it mean to you personally to be a finalist for the National Book Award? Was this one of your goals as a writer? Do you have bigger goals than this? 
KA: Being a finalist for the award was of course gratifying. I'm still surprised my work was chosen. It makes me take heart that there is a place in American poetry for the direct, the accessible, the communicative. There's nothing wrong with difficult poetry (that is, if it gets you somewhere real in the end and doesn't just leave you thinking, So what? I did all that work for that?) - but anyway, I can't write that kind of thing. I admire it, often, but it's not what I do. My work is pretty easy to understand. Where it's complex, I hope, is where life is complex. My goals as a writer have never changed since I started doing this seriously: I want to write well. I want to articulate my sense of what it's about, to be alive in a body that ages and dies, in this terrifying and amazing place. I don't know if that sounds like hyperbole, but it isn't. I am terrified and amazed to be here, most of the time. I drive down the street and stop at a light, and I don't know what the guy in the car next to me is thinking, but I'm going something like "Oh my God. It's all creation and destruction all the time."

When I was at San Francisco State, I studied with Stan Rice, who was enormously helpful to me-he took my work seriously before, frankly, it warranted it at all-and one of the things he said to me was, "After forty, you're writing for posterity." I didn't think so until I was around forty-five, and then I thought, yeah, that's what I'm doing. I'm writing these poems now but I want them to last, some of them anyway, and speak to someone after my death, the way poems by Sappho and Keats and Bishop have spoken to me. I guess that makes me pretty ambitious! But I want to leave something. I want to have made a contribution. As for winning awards, I'll be happy if that happens, too. More readers. More money. More opportunities to travel and see something of the world. More, more, more. More!

RVC: Have you run across any new poets lately that've impressed you? Is there anyone in particular that you tell your workshop students is a "must-read"?

KA: Younger poets I've found compelling would include Alice Anderson, Terrance Hayes, Jeff McDaniel, and Catie Rosemurgy. There's a lot of interesting stuff in a Carnegie Mellon anthology called American Poetry: The Next Generation. I'm interested in Anne 
Carson's work. I'm also a huge fan of C. K. Williams. But I'd have to say the latest poet I've read who really knocked me out is Edna St. Vincent Millay, and that I think she's been reincarnated as me.

RVC: How has it been working with independent and university presses such as BOA and FC2? With New York publishing budgets growing tighter all the time, are these types of presses the best venues for publishing poetry in America?

KA: I've been very happy with small presses. FC2 did my stories when no one else was interested in such weird shit. BOA took a leap of faith with my first and second books of poetry. By the third, I was a bit better established, and probably could have gone elsewhere, but I didn't want to. I think small presses may be the future of literature, period. Either that, or we'll all be down to memorizing books in order to preserve them, like in Ray Bradbury's Fahrenheit 451.

RVC: You have a reputation for being a very good reader of your own work. How did you develop the knack for giving a good poetic "performance"?

KA: I think the most important thing is to be inside the work when you're reading it. I don't consider myself a great performer or anything. I just try to get in touch with the space where the poem resides, so I can carry the energy of that to an audience. I think it's important to remember that the art has its roots in the oral tradition; the poet was the storyteller, the keeper of the myths. The job of the poet was-and is still-to be a singer, to continue the song.

RVC: What can we expect next from Kim Addonizio? Any new projects? More collaborations?

KA: Well, I'm in kind of a fertile period right now, with lots of things churning around but little time to do them. I feel like Keats when he wrote, "When I have fears that I may cease to be / before my pen has gleaned my teeming brain...." I have so much I just can't get to, I'm so swamped with student work, with trying to keep my life together. I'm working on new poems, a couple of new stories, and something else I don't want to talk about yet because it's too new 
and may not turn into anything. I just feel kind of desperate to check out of my life and write, but I can't do that, so I've got to wait. As for collaborations? God, no. What I want more than anything right now is to be totally alone.

RVC: This is a hard question, I know, but it's an important one. What's the future of poetry?

KA: Honestly, I don't know how to answer such global questions. I went to an event recently, though, put on by Youth Speaks, a local organization that does work with high school students. They just inaugurated a new literary space in the Mission district here, which seems incredible given the encroachment of the dot-commers, who are driving everybody out of this city. These kids were very alive, very involved with something they called poetry. Some of it was good, in terms of language, some of it was not so good. But there was a lot of energy, and a lot of focus on performance. Maybe that's the future of poetry - a return to, or a resurgence of, the oral tradition. (And all those memorized books from Fahrenheit 451 would fit in nicely.) I think poetry will continue to find its way, into the culture, into consciousness, in both the spoken and written word.

RVC: What was the best bit of writing advice you've ever received?

KA: The best advice I ever got was from my father, a year or so before he died. It was the single word, "Write!" He'd had a stroke and his words generally came out garbled, and I was in the hospital room showing him my first published poem, in a magazine put out by the undergraduate English Department at San Francisco State. He was partially paralyzed but managed to raise himself up, point at me and exclaim that one word before he fell back on the pillows.

To that advice I would add one more word: Read. People want to make it complicated, but I really think it's that simple. If you seriously read, and seriously write, that is all you need to guide you.

Okay, a third and final word: Persist. No matter what. 